\title{
Flavobacterium thalpophilum, a New Species Recovered from Human Clinical Material
}

\author{
B. HOLMES, ${ }^{1}$ D. G. HOLLIS, ${ }^{2 *}$ A. G. STEIGERWALT,${ }^{2}$ M. J. PICKETT ${ }^{3}$ AND DON J. BRENNER ${ }^{2}$ \\ National Collection of Type Cultures, Central Public Health Laboratory, London NW9 5HT, United \\ Kingdom ${ }^{1}$; Centers for Disease Control, Atlanta, Georgia $30333^{2}$; and Department of Microbiology, \\ University of California, Los Angeles, California $90024^{3}$
}

\begin{abstract}
We propose a new species, Flavobacterium thalpophilum. Each of the seven strains placed in this new species was examined for 129 characteristics, including 58 enzyme reactions (API ZYM System). These bacteria are rodshaped, aerobic, gram negative, and nonmotile and oxidize glucose in oxidation-fermentation medium. The mean guanine-plus-cytosine content of the deoxyribonucleic acids of seven strains is $45.0 \pm 0.8 \mathrm{~mol} \%$. The distinguishing features of the new species include an ability to reduce nitrate, an ability to grow at $42^{\circ} \mathrm{C}$, and an ability to produce acid from various carbohydrates and alcohols. In particular, the ability of $F$. thalpophilum strains to produce acid from adonitol distinguishes them from all other Flavobacterium species. The seven strains of the new species were isolated from human clinical specimens. The type strain is strain K-1173 (= NCTC 11429).
\end{abstract}

The name Flavobacterium multivorum was proposed by Holmes et al. (11) for strains that belonged to group Ilk, biotype 2 (21). Holmes et al. (11) also described two strains differing from F. multivorum in producing acid from ethanol and mannitol and in having a significantly higher proportion of guanine plus cytosine $(\mathrm{G}+\mathrm{C})$ in their deoxyribonucleic acid (DNA). For these 2 strains and 11 additional isolates the name Flavobacterium spiritivorum was proposed $(10)$. Holmes et al. (11) also described a group IIk, biotype 2 strain (strain 8291) which could not be included in $F$. multivorum, as it differed from this species in producing acid from adonitol, growing at $42^{\circ} \mathrm{C}$, reducing nitrate, and having a significantly higher proportion of $\mathrm{G}+\mathrm{C}$. Four strains with the latter characteristics were also described by Levine et al. (16), who also detected no DNA-DNA hybridization with an isolate representative of the majority of their strains belonging to group IIk, biotype 2 . The characteristics of strain 8291 from the study of Holmes et al. (11), the four similar strains from the study of Levine et al. (16), and two additional isolates are described here. We present evidence that these strains constitute a new species, for which we propose the name Flavobacterium thalpophilum.

\section{MATERIALS AND METHODS}

Bacterial strains. The seven bacterial strains studied (all from the United States) and the sources from which they were isolated are given in Table 1.

Bacteriological investigations. The methods which we used have been described previously (10).

$\mathbf{G}+\mathbf{C}$ content. The $\mathrm{G}+\mathrm{C}$ contents of DNAs were determined optically by thermal denaturation (5).
Escherichia coli B DNA ( $\mathrm{G}+\mathrm{C}$ content, $51.2 \mathrm{~mol} \%)$ was used as a control.

DNA relatedness. The preparation and purification of DNA and the conditions used to determine DNA relatedness by the hydroxyapatite method have been described previously (2). DNA from $F$. thalpophilum strain $\mathrm{K}-1173^{\mathrm{T}}$ ( $\mathrm{T}=$ type strain) was labeled with ${ }^{32} \mathrm{PO}_{4}$ in vitro (3).

\section{RESULTS}

Phenotypic characteristics of $\boldsymbol{F}$. thalpophilum. The seven strains which we studied were strictly aerobic, gram-negative, uniformly staining rods with parallel sides and rounded ends. After $48 \mathrm{~h}$ at $30^{\circ} \mathrm{C}$, colonies on nutrient agar were circular, 0.5 to $2 \mathrm{~mm}$ in diameter (except strain K-1232, which formed pinpoint colonies), low convex, smooth, and opaque. A pale yellow pigment that was nondiffusible and nonfluorescent was produced by strains 8291, C499, and E8209 within 5 days and by the remaining strains after 5 days. None of the strains produced a dark brown pigment on tyrosine agar. The strains grew well at room temperature and at 30,37 , and $42^{\circ} \mathrm{C}$ but failed to grow at $5^{\circ} \mathrm{C}$. Hemolysis was not present after aerobic growth for $24 \mathrm{~h}$. A total of 112 characteristics were common to all strains (either all positive or all negative; see below), and there were 17 characteristics in which one or more of the strains differed (Table 2). Strain K$1173^{\mathrm{T}}$ was the centrotype (there was no median organism). Strains 8291 and K-1232 were the least typical members of $F$. thalpophilum: the former differed from the other six strains in four biochemical characteristics, whereas the latter differed from the other six strains in two different biochemical characteristics. 
TABLE 1. Strains of $F$. thalpophilum sp. nov. studied

\begin{tabular}{ll}
\hline \multicolumn{1}{c}{ Strain } & \multicolumn{1}{c}{ Isolated from: } \\
\hline 8291 & Blood; Louisiana \\
B5832 & Wound; New York City \\
C499 $(=\mathrm{K}-1207=$ & Abscess; Tennessee \\
NCTC 11430) & \\
E8209 & Blood; Texas \\
K-997 & Leg wound; California \\
$\mathrm{K}-1173^{\mathrm{T}}(=$ NCTC & Wound; New York City \\
$\left.11429^{\mathrm{T}}\right)$ & \\
$\mathrm{K}-1232(=$ NCTC & Foot wound; California \\
$11431)$ & \\
\hline
\end{tabular}

All seven strains were resistant to therapeutic levels of the following antimicrobial agents (minimum inhibitory concentrations indicated in parentheses): ampicillin $(64 \mu \mathrm{g} / \mathrm{ml})$, carbenicillin (32 to $128 \mu \mathrm{g} / \mathrm{ml}$ ), cephalothin $(128 \mu \mathrm{g} / \mathrm{ml}$ ), amikacin $(>32 \mu \mathrm{g} / \mathrm{ml})$, gentamicin $(\geq 32 \mu \mathrm{g} / \mathrm{ml})$, kanamycin $(>32 \mu \mathrm{g} / \mathrm{ml})$, tobramycin $(>32 \mu \mathrm{g} /$ $\mathrm{ml})$, and chloramphenicol $(>8 \mu \mathrm{g} / \mathrm{ml})$. One strain was susceptible $(1 \mu \mathrm{g} / \mathrm{ml})$ and six were resistant $(64 \mu \mathrm{g} / \mathrm{ml})$ to tetracycline; all strains were susceptible to rifampin $(0.5$ to $2 \mu \mathrm{g} / \mathrm{ml})$.

$\mathbf{G}+\mathbf{C}$ content of $\boldsymbol{F}$. thalpophilum DNA. $\mathrm{G}+\mathrm{C}$ contents were determined for seven strains of $F$. thalpophilum and for the type strains of $F$. multivorum, and $F$. spiritivorum. The average \% $\mathrm{G}+\mathrm{C}$ content of $F$. thalpophilum was $45.0 \pm 0.8$ mol\% (range, 43.8 to $46.0 \mathrm{~mol} \%$ ). The $\mathrm{G}+\mathrm{C}$ contents of the type strains of $F$. thalpophilum, $F$. multivorum, and $F$. spiritivorum were 43.8 ,
40.8 , and $41.6 \mathrm{~mol} \%$, respectively. The two latter values are in good agreement with previously published values (Table 3 ).

DNA relatedness. The levels of relatedness of labeled $F$. thalpophilum DNA to unlabeled DNAs from six other $F$. thalpophilum strains were 64 to $96 \%$ (average, $74 \%$ ) in reactions done at a temperature that was close to optimal for DNA reassociation and 63 to $96 \%$ (average, $74 \%$ ) in reactions done at $75^{\circ} \mathrm{C}$, where only very closely related DNA sequences can reassociate (Table 4). The levels of divergence (percentage of unpaired bases) within related sequences were 0.5 to $1.5 \%$. The levels of relatedness of $F$. thalpophilum to the type strains of $F$. multivorum and $F$. spiritivorum were 20 and $12 \%$, respectively.

\section{DISCUSSION}

The results presented above indicate that the seven strains of gram-negative, yellow-pigmented bacteria for which the name Flavobacterium thalpophilum (thal.po'phi.lum. Gr. n. thalpos warmth; Gr. n. adj. philon loving; M. L. n. adj. thalpophilum warmth-loving) is here proposed constitute a homogeneous taxon. This new species conforms phenotypically to the definition of Flavobacterium as emended by Holmes and Owen (7), although members of the species are not markedly yellow pigmented and (like $F$. multivorum and $F$. spiritivorum) are less active proteolytically than other species in the genus (i.e., Flavobacterium balustinum, Flavobacter-

TABLE 2. Characteristics for which the seven strains of $F$. thalpophilum gave different results

\begin{tabular}{|c|c|c|c|}
\hline Characteristic & $\begin{array}{l}\text { No. of strains } \\
\text { positive }\end{array}$ & $\begin{array}{l}\text { Result for type } \\
\text { strain K-1173 }\end{array}$ & $\begin{array}{l}\text { Strain(s) that gave the less } \\
\text { common result }\end{array}$ \\
\hline Acid from peptone-water-glucose & 6 & + & C499 \\
\hline Deoxyribonuclease production & 6 & + & $\mathrm{K}-1232$ \\
\hline Gelatin hydrolysis (plate method) & 6 & + & 8291 \\
\hline \multicolumn{4}{|l|}{ Hydrolysis of: } \\
\hline L-Valyl-2-naphthylamide ${ }^{a, b}$ & 6 & + & K-1232 \\
\hline 6-Bromo-2-naphthyl- $\beta$-D-glucopyranoside $\mathrm{e}^{a, b}$ & 5 & + & $8291, \mathrm{~K}-1232$ \\
\hline L-Tyrosyl- $\beta$-naphthylamide ${ }^{a}$ & 5 & + & 8291, B 5832 \\
\hline 6-Bromo-2-naphthyl- $\alpha$-D-galactopyranoside ${ }^{a, b}$ & 4 & + & $8291, \mathrm{~B} 5832, \mathrm{~K}-997$ \\
\hline 2-Naphthyl- $\beta$-D-galactopyranoside $\mathrm{e}^{a, b}$ & 4 & + & 8291, B5832, K-997 \\
\hline 2-Naphthyl- $\alpha$-L-fucopyranoside $\mathrm{e}^{a, b}$ & 4 & + & $8291, \mathrm{~B} 5832, \mathrm{~K}-997$ \\
\hline$p$-Nitrocathechol sulfate ${ }^{a}$ & 4 & + & $8291, \mathrm{~K}-997, \mathrm{~K}-1232$ \\
\hline 4-Methylumbelliferylarabinopyranoside ${ }^{a}$ & 3 & - & $8291, \mathrm{E} 8209, \mathrm{~K}-1232$ \\
\hline $\begin{array}{l}N \text {-Carbobenzoxy-L-arginine-4-methoxy- } \beta \text { - } \\
\text { naphthylamide hydrochloride }{ }^{a}\end{array}$ & 3 & + & $\mathrm{C} 499, \mathrm{E} 8209, \mathrm{~K}-1173^{\mathrm{T}}$ \\
\hline $\begin{array}{l}\text { Production of yellow pigment } \\
\text { Hydrolysis of: }\end{array}$ & 3 & - & $8291, \mathrm{C} 499, \mathrm{E} 8209$ \\
\hline L-Phenylalanyl- $\beta$-naphthylamide ${ }^{a}$ & 2 & - & $\mathrm{E} 8209, \mathrm{~K}-997$ \\
\hline 2-Naphthyl caprylate ${ }^{a, b}$ & $\overline{1}$ & - & 8291 \\
\hline Bis-(p-nitrophenyl)-phosphate ${ }^{a}$ & 1 & - & 8291 \\
\hline$p$-Nitrophenyl lactoside ${ }^{a}$ & 1 & - & 8291 \\
\hline
\end{tabular}

\footnotetext{
${ }^{a}$ Tested by using various API ZYM galleries.

${ }^{b}$ Enzyme test included in the standard API ZYM gallery.
} 
ium breve, Flavobacterium meningosepticum, and Flavobacterium odoratum). Furthermore, the $\mathrm{G}+\mathrm{C}$ values of 44 to $46 \mathrm{~mol} \%$ obtained for $F$. thalpophilum are higher than the values obtained for other recognized species of Flavobacterium (Table 3). The inclusion of $F$, thalpophilum in the genus thus widens the $\mathrm{G}+\mathrm{C}$ range of Flavobacterium (7) to 31 to $46 \mathrm{~mol} \%$. Since this is a wide range for a bacterial genus, $F$. mult $i$ vorum, $F$. spiritivorum, and $F$. thalpophilum could be moved to a new genus along the lines suggested by Holmes and Owen (8). However, there are insufficient phenotypic differences to create a new genus. Characteristics for the practical identification of the new species are shown in Table 3. Pseudomonas paucimobilis is included in Table 3 because it has biochemical properties similar to those of $F$. multivorum, $F$. spiritivorum, and $F$. thalpophilum. Table 3 shows that the new species is most similar to $F$. multivorum. There are consistent differences between $F$. multivorum and $F$. thalpophilum in three conventional tests (production of acid in ammonium salt medium from adonitol; growth at $42^{\circ} \mathrm{C}$, and reduction of nitrate) but not in any API ZYM test. The mean $\mathrm{G}+\mathrm{C}$ content of the strains of the new species which we examined $(45.0 \mathrm{~mol} \%)$ is slightly higher than the previously published values for $F$. multivorum $(39.6 \mathrm{~mol} \%$ $\mathrm{G}+\mathrm{C}$ [present study, $40.8 \mathrm{~mol} \%$ ]) and $F$. spiritivorum (41.4 mol\% $\mathrm{G}+\mathrm{C}$ [present study, 41.6 mol\%]). DNA relatedness studies showed that the seven strains of $F$. thalpophilum tested constitute a single species that is distinct from $F$. multivorum and $F$. spiritivorum. The levels of relatedness of the type strain to some other strains are 64 to $69 \%$, values which are slightly lower than the levels of relatedness $(70 \%$ or more) that are usually observed between strains of a single species (2). The very low levels of sequence divergence among these strains and the fact that the levels of relatedness remain high in reactions performed at the stringent $75^{\circ} \mathrm{C}$ incubation temperature (63 to $78 \%$ ) insure the validity of assigning all of the strains to a single species. Previously, the DNAs of strains K$1173^{\mathrm{T}}$ and $\mathrm{K}-1232$ showed no hybridization with the DNA of a strain of $F$. multivorum (16).

All of the strains of $F$. thalpophilum were isolated from clinical specimens, and blood and wounds were the most common sources. The clinical significance of these organisms cannot be assessed at present, but their resistance to a wide range of antimicrobial agents indicates that any infections in humans due to such bacteria could prove difficult to treat. Resistance to antimicrobial agents is a characteristic that $F$. thalpophilum shares with the other Flavobacterium species $(1,11-15,22)$.

Description of the species and the type strain.
The characteristics for which all seven strains of the species gave either positive results or negative results are given below. Characteristics for which the seven strains gave different results are given in Table 2 .

Gram-negative, nonsporeforming rods of regular shape with rounded ends. Nonmotile in hanging-drop preparations after overnight growth in nutrient broth incubated at either $37^{\circ} \mathrm{C}$ or room temperature $\left(18\right.$ to $\left.22^{\circ} \mathrm{C}\right)$.

Circular, low convex, smooth, opaque colonies develop on nutrient agar after 2 days; colonies nonhemolytic on $5 \%(\mathrm{vol} / \mathrm{vol})$ horse blood agar; on nutrient agar, eventual production of a yellow pigment which is not fluorescent. No production of brown pigment on tyrosine agar.

\section{Aerobic.}

Growth at room temperature and at 37 and $42^{\circ} \mathrm{C}$, but not at $5^{\circ} \mathrm{C}$.

Production of catalase and cytochrome oxidase.

\section{Production of urease}

Does not tolerate $\mathrm{KCN}$ at a concentration of $0.0075 \%$ (wt $/ \mathrm{vol})$. Hydrolysis of Tween 20 and Tween 80.

No production of opalescence on lecithovitellin agar.

Reduction of nitrate to nitrite; no reduction of nitrite.

No production of indole or hydrogen sulfide.

Growth on $\beta$-hydroxybutyrate (without production of lipid inclusion granules) and on MacConkey agar, but not on cetrimide agar.

No digestion of casein.

Hydrolysis of esculin and tributyrin, but not starch or tyrosine.

No utilization of citrate or malonate.

No oxidation of gluconate.

No production of arginine deimidase, arginine deiminase, lysine decarboxylase, or ornithine decarboxylase.

No production of 3-ketolactose.

No reduction of selenite and no deamination of phenylalanine.

Production of phosphatase and $\beta$-D-galactosidase (when tested by method 1 of Cowan [4] and the method of Holmes et al. [6], respectively).

Production of acid in ammonium salt medium under aerobic conditions from glucose, adonitol, arabinose, cellobiose, fructose, glycerol, lactose, maltose, raffinose, rhamnose, salicin, sucrose, trehalose, and xylose.

Production of acid from $10 \%(\mathrm{wt} / \mathrm{vol})$ glucose and $10 \%$ (wt/vol) lactose.

No production of acid in ammonium salt medium under aerobic conditions from dulcitol, ethanol, inositol, mannitol, or sorbitol.

No production of gas from glucose in peptone- 
TABLE 3. Characteristics for practical identification and differentiation of $F$. thalpophilum from other Flavobacterium taxa and from Pseudomonas

\begin{tabular}{|c|c|c|c|c|c|c|c|c|c|}
\hline Test & $\begin{array}{l}\text { F. thalpo- } \\
\text { philum (7 } \\
\text { strains) }\end{array}$ & $\begin{array}{l}\text { F. multi- } \\
\text { vorum ( } 28 \\
\text { strains) }\end{array}$ & $\begin{array}{l}\text { F. spirit- } \\
\text { ivorum }(13 \\
\text { strains) }\end{array}$ & $\begin{array}{l}\text { F. balu- } \\
\text { stinum }(1 \\
\text { strain) }\end{array}$ & $\begin{array}{l}\text { F. breve } \\
\text { (7 strains) }\end{array}$ & $\begin{array}{l}F . \text { meningo- } \\
\text { septicum (49 } \\
\text { strains) }\end{array}$ & $\begin{array}{c}\text { Flavobac- } \\
\text { terium } \\
\text { species group } \\
\text { IIb (55 } \\
\text { strains) }\end{array}$ & $\begin{array}{l}\text { F. odoratum } \\
\text { (28 strains) }\end{array}$ & $\begin{array}{l}\text { P. pauci- } \\
\text { mobilis (29 } \\
\text { strains) }\end{array}$ \\
\hline \multicolumn{10}{|l|}{$\begin{array}{l}\text { Acid from ammonium salt- } \\
\text { sugar medium containing: }\end{array}$} \\
\hline Glucose & $+^{b}$ & + & + & + & $6 / 7^{c}$ & $42 / 49$ & + & - & + \\
\hline Adonitol & + & - & - & - & - & - & - & - & - \\
\hline Arabinose & + & + & $3 / 1 ?$ & - & - & $1 / 49$ & $13 / 55$ & - & + \\
\hline Cellobiose & + & + & + & - & - & $4 / 49$ & $3 / 55$ & - & + \\
\hline Ethanol & - & - & + & + & - & $28 / 49$ & $9 / 55$ & - & $26 / 29$ \\
\hline Glycerol & + & $27 / 28$ & + & - & - & $38 / 49$ & $35 / 55$ & - & $6 / 29$ \\
\hline Lactose & + & + & + & - & - & $27 / 49$ & - & - & + \\
\hline Maltose & + & + & + & - & $6 / 7$ & $46 / 49$ & + & - & + \\
\hline Mannitol & - & - & + & - & - & $31 / 49$ & $3 / 55$ & - & - \\
\hline Raffinose & + & + & + & - & - & - & - & - & $28 / 29$ \\
\hline Rhamnose & + & $13 / 28$ & $1 / 13$ & - & - & - & $1 / 55$ & - & $5 / 29$ \\
\hline Salicin & + & + & + & - & - & - & $1 / 55$ & - & $26 / 29$ \\
\hline Sucrose & + & + & + & - & - & - & $12 / 55$ & - & + \\
\hline Trehalose & + & + & + & - & - & $42 / 49$ & $48 / 55$ & - & + \\
\hline Xylose & + & + & + & - & - & $3 / 49$ & 9/55 & - & + \\
\hline Casein digestion & - & - & - & + & + & + & + & + & - \\
\hline Esculin hydrolysis & + & + & + & + & - & $47 / 49$ & $52 / 55$ & - & + \\
\hline $\begin{array}{l}\text { Gelatinase production (plate } \\
\text { method) }\end{array}$ & $6 / 7$ & $4 / 28$ & + & + & + & + & + & + & $3 / 29$ \\
\hline Growth at $42^{\circ} \mathrm{C}$ & + & - & - & - & - & $6 / 49$ & $15 / 55$ & - & - \\
\hline Growth on MacConkey agar & + & + & + & + & + & + & $51 / 55$ & + & - \\
\hline $\begin{array}{l}\text { Indole production (Ehrlich } \\
\text { reagent) }\end{array}$ & - & - & - & + & + & $24 / 49$ & $53 / 55$ & - & - \\
\hline Motility at room temperature & - & - & - & - & - & - & - & - & $22 / 29$ \\
\hline Nitrate reduction & + & - & - & + & - & $2 / 49$ & $16 / 55$ & - & - \\
\hline Nitrite reduction & - & - & - & - & - & $18 / 49$ & $14 / 55$ & + & - \\
\hline $\begin{array}{l}\text { Poly- } \beta \text {-hydroxybutyrate in- } \\
\text { clusion granules }\end{array}$ & - & - & - & - & - & - & - & - & $25 / 29$ \\
\hline Starch hydrolysis & - & - & - & - & - & - & $36 / 55$ & - & $18 / 29$ \\
\hline Urease production & + & $27 / 28$ & + & - & - & $16 / 49$ & $11 / 55$ & + & - \\
\hline
\end{tabular}


TABLE 4. Levels of DNA relatedness among $F$.

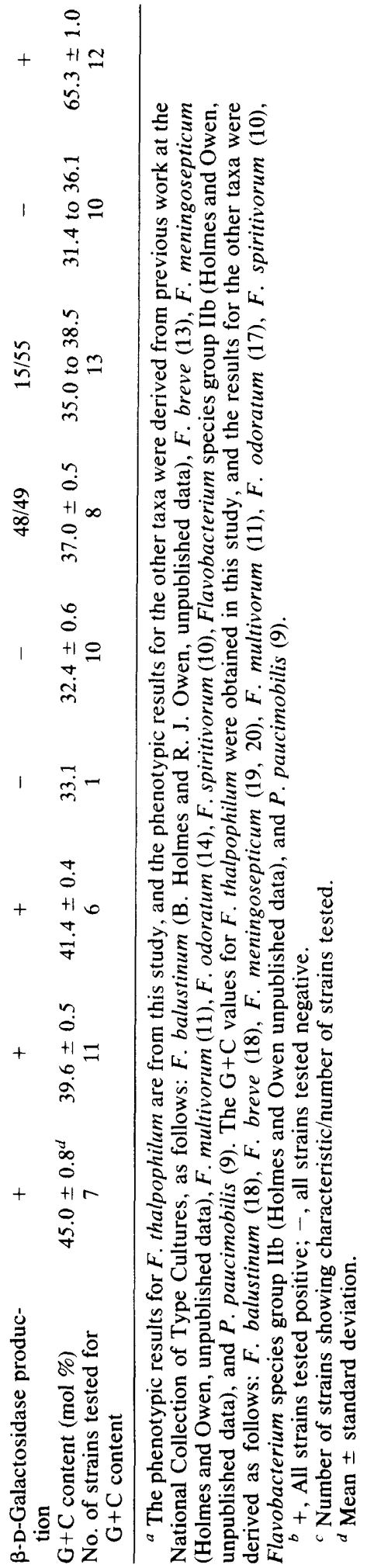
thalpophilum strains $^{a}$

\begin{tabular}{|c|c|c|c|c|}
\hline \multicolumn{2}{|c|}{ Source of unlabeled DNA } & \multicolumn{3}{|c|}{$\begin{array}{l}{ }^{32} \mathrm{PO}_{4} \text {-labeled DNA from } F \text {. } \\
\text { thalpophilum strain } \mathrm{K}-1173^{\mathrm{T}}\end{array}$} \\
\hline Species & Strain & $\begin{array}{l}\text { Relative } \\
\text { binding } \\
\text { index at } \\
60^{\circ} \mathrm{C}(\%)\end{array}$ & $\begin{array}{c}\text { Divergence } \\
(\%)\end{array}$ & $\begin{array}{l}\text { Relative } \\
\text { binding } \\
\text { index at } \\
75^{\circ} \mathrm{C}(\%)\end{array}$ \\
\hline \multirow[t]{7}{*}{ F. thalpophilum } & K-1173 ${ }^{\mathbf{T}}$ & 100 & 0.0 & 100 \\
\hline & C499 & 96 & 0.5 & 96 \\
\hline & E8209 & 85 & 0.5 & 78 \\
\hline & B5832 & 69 & 0.5 & 74 \\
\hline & 8291 & 66 & 0.5 & 67 \\
\hline & $\mathrm{K}-1232$ & 65 & 0.5 & 67 \\
\hline & K-997 & 64 & 1.5 & 63 \\
\hline F. multivorum & B5533 & 20 & $\mathrm{NT}^{b}$ & NT \\
\hline F. spiritivorum & E7288 & 12 & NT & NT \\
\hline
\end{tabular}

${ }^{a}$ The relative binding index was calculated as follows: (percent heterologous DNA bound to hydroxyapatite/percent homologous DNA bound to hydroxyapatite) $\times 100$. Divergence was calculated on the assumption that each $1{ }^{\circ} \mathrm{C}$ decrease in the thermal stability of a heterologous DNA compared with that of the homologous DNA duplex was caused by $1 \%$ unpaired bases within the duplex. Divergence was calculated to the nearest $0.5 \%$. The values shown are averages. All reactions were done twice. Before normalization to $100 \%$, the percentages of DNA bound to hydroxyapatite in homologous reactions were 43 to $50 \%$. The amount of labeled DNA that bound to hydroxyapatite in control reactions that did not contain unlabeled DNA was $1 \%$ at 60 and $75^{\circ} \mathrm{C}$. These control values were subtracted from all reassociation reaction values before normalization.

${ }^{b}$ NT, Not tested.

water medium; production of acid in only open tubes of Hugh-Leifson oxidation-fermentation glucose medium.

Hydrolysis of the following substrates (using API ZYM galleries): 2-naphthyl phosphate at $\mathrm{pH}$ 8.5; L-leucyl-2-naphthylamide; 2-naphthyl phosphate at $\mathrm{pH} 5.4$; naphthol-AS-B1-phosphodiamide; 2-naphthyl- $\alpha$-D-glucopyranoside; 1-naphthyl- $N$-acetyl- $\beta$-D-glucosaminide; 4-methylumbelliferyl-cellobiopyranoside; L-pyrrolidonyl- $\beta$ naphthylamide; L-lysyl- $\beta$-naphthylamide; L-histidyl- $\beta$-naphthylamide; glycyl- $\beta$-naphthylamide; $L$-aspartyl- $\beta$-naphthylamide; L-arginyl- $\beta$ naphthylamide; L-alanyl- $\beta$-naphthylamide; $\gamma$-Lglutamyl- $\beta$-naphthylamide; $S$-benzyl-L-cysteyl$\beta$-naphthylamide; DL-methionyl- $\beta$-naphthylamide; glycyl-glycyl- $\beta$-naphthylamide hydrobromide; glycyl-L-phenylalanyl- $\beta$-naphthylamide; glycyl-L-prolyl- $\beta$-naphthylamide; L-leucyl-glycyl- $\beta$-napthylamide; $\quad$ L-seryl-L-tyrosyl- $\beta$-naphthylamide; L-glutamine- $\beta$-naphthylamide hydrochloride; $\alpha$-L-glutamyl- $\beta$-naphthylamide; L-ornithyl- $\beta$-naphthylamide; $L$-seryl- $\beta$-naphthylamide; L-threonyl- $\beta$-naphthylamide; L-tryptophyl- $\beta$ naphthylamide; and $N$-carbobenzoxy-glycyl- 
glycyl-L-arginine- $\beta$-naphthylamide.

No hydrolysis of the following substrates (using API ZYM galleries): 2-naphthyl butyrate; 2naphthyl myristate; L-cystyl-2-naphthylamide; $\mathrm{N}$-benzoyl-DL-arginine-2-naphthylamide; $\mathrm{N}$-glutaryl-phenylalanine-2-naphthylamide; naphtholAS-B1- $\beta$-D-glucuronic acid; 6-bromo-2-naphthyl- $\alpha$-D-mannopyranoside; 6-bromo-2-naphthyl- $\beta$-D-xylopyranoside; $p$-nitrophenyl- $\alpha-D-x y-$ lopyranoside; $p$-nitrophenyl- $\beta$-D-fucopyranoside; $p$-nitrophenyl- $\beta$-L-fucopyranoside; $o$-nitrophenyl- $N$-acetyl- $\alpha$-D-glucosaminide; L-hydroxyprolyl- $\beta$-naphthylamide; $N$-benzoyl-L-leucyl- $\beta$ naphthylamide; $L$-isoleucyl- $\beta$-naphthylamide; $L$ prolyl- $\beta$-naphthylamide hydrochloride.

Resistant to ampicillin, carbenicillin, cephalothin, amikacin, gentamicin, kanamycin, tobramycin, chloramphenicol, and tetracycline (strain $\mathrm{K}-1232$ is susceptible). Susceptible to rifampin.

The $\mathrm{G}+\mathrm{C}$ content of the DNA: is $45.0 \pm 0.8$ mol\%, and the $\mathrm{G}+\mathrm{C}$ content of the DNA of the type strain is $43.8 \mathrm{~mol} \%$, as estimated by the thermal denaturation method.

Source of type strain: wound (human).

The following two additional strains of $F$. thalpophilum have been deposited in the National Collection of Type Cultures: C499 (= K-1207) as NCTC 11430 and K-1232 as NCTC 11431.

\section{ACKNOWLEDGMENTS}

We are most grateful to R. E. Weaver for advice and encouragement, to Carolyn Baker for assistance with the antimicrobial susceptibility determinations and to API System S.A. for a supply of ZYM galleries. We thank T. O. MacAdoo for advising us on the etymology of the new specific epithet. E. Roe is thanked for secretarial assistance, and we thank E. Cain for laboratory assistance.

\section{LITERATURE CITED}

1. Altmann, G., and B. Bogokovsky. 1971. In-vitro sensitivity of Flavobacterium meningosepticum to antimicrobial agents. J. Med. Microbiol. 4:296-299.

2. Brenner, D. J., A. C. McWhorter, J. K. Leete Knutson, and A. G. Steigerwalt. 1982. Escherichia vulneris: a new species of Enterobacteriaceae associated with human wounds. J. Clin. Microbiol. 15:1133-1140.

3. Brenner, D. J., A. G. Steigerwalt, R. E. Weaver, J. E. McDade, J. C. Feeley, and M. Mandel. 1978. Classification of the Legionnaires' disease bacterium: an interim report. Curr. Microbiol. 1:71-75.

4. Cowan, S. T. 1974. Cowan and Steel's manual for the identification of medical bacteria, 2nd ed. Cambridge University Press, London.

5. DeLey, J. 1970. Reexamination of the association between melting point, buoyant density, and chemical base composition of deoxyribonucleic acid. J. Bacteriol. 101:738-754.

6. Holmes, B., S. P. Lapage, and H. Malnick. 1975. Strains of Pseudomonas putrefaciens from clinical material. J. Clin. Pathol. 28:149-155.
7. Holmes, B., and R. J. Owen. 1979. Proposal that Flavobacterium breve be substituted as the type species of the genus in place of Flavobacterium aquatile and emended description of the genus Flavobacterium: status of the named species of Flavobacterium. Request for an Opinion. Int. J. Syst. Bacteriol. 29:416-426.

8. Holmes, B., and R. J. Owen. 1981. Emendation of the genus Flavobacterium and the status of the genus. Developments after the 8th edition of Bergey's Manual, p. 17 26. In $\mathrm{H}$. Reichenbach and $\mathrm{O}$. B. Weeks (ed.), The Flavobacterium-Cytophaga group. Proceedings of the International Symposium on Yellow-Pigmented Gram-Negative Bacteria of the Flavobacterium-Cytophaga Group Braunschweig, July 8 to 11,1980 . Verlag Chemie, Weinheim.

9. Holmes, B., R. J. Owen, A. Evans, H. Malnick, and W. R. Willcox. 1977. Pseudomonas paucimobilis, a new species isolated from human clinical specimens, the hospital environment, and other sources. Int. J. Syst. Bacteriol. 27:133-146.

10. Holmes, B., R. J. Owen, and D. G. Hollis. 1982. Flavobacterium spiritivorum, a new species isolated from human clinical specimens. Int. J. Syst. Bacteriol. 32:157-165.

11. Holmes, B., R. J. Owen, and R. E. Weaver. 1981. Flavobacterium multivorum, a new species isolated from human clinical specimens and previously known as group IIk, biotype 2. Int. J. Syst. Bacteriol. 31:21-34.

12. Holmes, B., J. J. S. Snell, and S. P. Lapage. 1977. Revised description, from clinical isolates, of Flavobacterium odoratum Stutzer and Kwaschnina 1929, and designation of the neotype strain. Int. J. Syst. Bacteriol. 27:330-336.

13. Holmes, B., J. J. S. Snell, and S. P. Lapage. 1978. Revised description, from clinical strains, of Flavobacterium breve (Lustig) Bergey et al. 1923 and proposal of the neotype strain. Int. J. Syst. Bacteriol. 28:201-208.

14. Holmes, B., J. J. S. Snell, and S. P. Lapage. 1979. Flavobacterium odoratum: a species resistant to a wide range of antimicrobial agents. J. Clin. Pathol. 32:73-77.

15. King, E. O. 1959. Studies on a group of previously unclassified bacteria associated with meningitis in infants. Am. J. Clin. Pathol. 31:241-247.

16. Levine, M. G., M. J. Pickett, and M. Mandel. 1980 Taxonomy of nonfermentative bacilli: the IIk-2 group. Curr. Microbiol. 4:41-44.

17. Owen, R. J., and B. Holmes. 1978. Heterogeneity in the characteristics of deoxyribonucleic acid from Flavobacterium odoratum. FEMS Microbiol. Lett. 4:41-46.

18. Owen, R. J., and B. Holmes. 1980. Differentiation between strains of Flavobacterium breve and allied bacteria by comparisons of deoxyribonucleic acids. Curr. Microbiol. 4:7-11.

19. Owen, R. J., and S. P. Lapage. 1974. A comparison of strains of King's group IIb of Flavobacterium with Flavobacterium meningosepticum. Antonie van Leeuwenhoek J. Microbiol. Serol. 40:255-264.

20. Owen, R. J., and J. J. S. Snell. 1976. Deoxyribonucleic acid reassociation in the classification of flavobacteria. J. Gen. Microbiol. 93:89-102.

21. Tatum, H. W., W. H. Ewing, and R. E. Weaver. 1974 Miscellaneous gram-negative bacteria, p. 270-294. In E. H. Lennette, E. H. Spaulding, and J. P. Truant (ed.), Manual of clinical microbiology, 2nd ed. American Society for Microbiology, Washington, D.C

22. Von Graevenitz, A., and M. Grehn. 1977. Susceptibility studies on Flavobacterium II-b. FEMS Microbiol. Lett. 2:289-292. 